\title{
UNDERPRICING OF IPOS THAT FOLLOW PRIVATE PLACEMENT
}

\author{
Kelly Nianyun Cai, Hei Wai Lee, and Vivek Sharma \\ University of Michigan-Dearborn
}

\begin{abstract}
In this study we examine the underpricing of initial public offerings (IPOs) by firms that have private placements of equity before their IPOs (PP IPO firms). We find that PP IPOs are associated with significantly less underpricing than their peers. Furthermore, PP IPOs are associated with lower underwriting spreads, more reputable underwriting syndicates, and greater postissue analyst coverage as compared to IPOs that are issued by their industry peers under similar market conditions. Consistent with the implications of the information asymmetry explanation for IPO underpricing, our findings suggest that companies could benefit by conveying their quality via successful pre-IPO private placements that help reduce the cost of going public.
\end{abstract}

JEL Classification: G24, G32

\section{Introduction}

Recent studies examine initial public offering (IPO) underpricing of firms that have a prior history of external funding activities and document findings consistent with the information asymmetry explanation. Cai, Ramchand, and Warga (2004) examine underpricing of firms that have public debt offerings before their IPOs and find significantly less underpricing for these issuers. The public awareness and monitoring of these issuing firms resulting from their pre-IPO public debt offerings reduces the degree of information asymmetry on their quality, which leads to less underpricing of their IPOs. James (1987) and Stein (2002) show that bank loans may have positive effects on the valuation of borrowing firms. By granting a loan, banks implicitly disclose part of their proprietary information about the borrowers and certify the financial conditions of borrowing firms. Furthermore, Schenone (2004) shows that issuing firms with pre-IPO banking relationships face less IPO underpricing, suggesting that the certifying capacity of banks ameliorates the degree of information asymmetry about the quality of issuing firms.

As another form of external funding activities, pre-IPO private placements of equity may reduce IPO underpricing of issuing firms. First, private placements allow privately held firms to introduce themselves to the investment community before their IPOs. Information about the completed private placement is usually available to general

We are very grateful to Jayant R. Kale (the editor) and an anonymous referee whose comments and suggestions significantly improved the paper. We would also like to thank Jean Helwege, Xuejing Xing and the conference participants of Financial Management Association annual conference (2006), Journal of Banking and Finance 30th anniversary conference, and Midwest Finance Association annual conference (2006). We are solely responsible for any remaining errors. 
investors via media coverage such as announcements in the Wall Street Journal and other investment publications such as Private Placement Letters. The availability of such information facilitates the public awareness of the issuing firm before its IPO and hence reduces the degree of information asymmetry on the issuer's quality and value. To the extent that a greater degree of information asymmetry leads to a higher level of IPO underpricing, issuing firms that have pre-IPO private placements would experience less underpricing at the time of their IPOs. However, we acknowledge the potential selection bias in our sample if only successful private placement issuers would go public. If such bias were present in the sample, the underpricing of PP IPOs could not be interpreted exclusively on the causality between IPO underpricing and the resolution of information asymmetry. But information asymmetry could still be a viable explanation for PP IPO underpricing because investors would interpret a successful pre-IPO private placement as a valuable signal about the PP IPO firm in their pricing decisions.

Second, the certifying role played by pre-IPO private placement investors could signal the quality of the firm. Similar to banking relationships, private placements provide an effective channel for issuing firms to convey valuable information concerning their quality to target institutional investors and high-net-worth, knowledgeable individual investors. The participation of informed private placement investors could be considered as a certification of the quality of the issuing firm that may lead to less underpricing of its IPO.

Third, the monitoring role played by active institutional investors participating in the pre-IPO private placements could improve efficient use of corporate resources that further enhances the quality of issuing firms (Wruck 1989). This may further reduce the underpricing of IPOs of firms that have successful private placements of equity before going public.

In this study, we examine IPO underpricing of a sample of 500 PP IPO firms (firms that had at least a successful pre-IPO private placement of equity) relative to that of their peers, which did not have private placements before their IPOs during 1981-2002. We find that PP IPOs experience significantly less underpricing than their peers, even after we control for factors that are known to affect IPO underpricing.

In further analysis, we find some support for the role of asymmetric information in explaining the lesser underpricing of PP IPOs. Using the availability of pre-IPO data on the Compustat database as a proxy for the information environment faced by issuing firms before their IPOs, we find that pre-IPO data are available for a larger portion of the PP IPOs sample than for the matched sample. In addition, we find that there is a significantly larger portion of PP IPOs that are covered by analysts than that for the matched sample. These results are consistent with the notion that pre-IPO private placements help mitigate the level of information asymmetry of issuing firms.

Our findings, however, provide much weaker support for the certification explanation. The PP IPOs placed with informed investors show less underpricing relative to those placed with uninformed investors. However, the difference is not significant. Besides, we find that PP IPO issuers experience significantly less underpricing than their matched IPO peers, regardless of whether their private placements are placed with informed or uninformed investors. There is limited support for the monitoring role of preIPO private placement investors in reducing IPO underpricing. Our results indicate that 
IPO issuers with their pre-IPO equity privately placed with active monitoring investors experience significantly less underpricing than their matched IPO peers. On the other hand, underpricing of PP IPOs with their pre-IPO equity placed with passive investors is comparable with that of their peers. However, PP IPOs placed with active monitoring investors do not show significant less underpricing relative to those placed with passive investors.

In addition, we examine the long-term stock return performance PP IPOs relative to their peers using the Fama (1993) and Mitchell and Stafford (2000) calendar-time portfolio approach. We find that PP IPOs, similar to their peers, do not show risk-adjusted abnormal stock returns over an extended three-year horizon.

Consistent with recent findings on IPO underpricing of issuing firms that have prior external funding activities (Cai, Ramchand, and Warga 2004; Schenone 2004), our results indicate that successful pre-IPO private placements of equity lower issuance costs, both indirect (underpricing) and direct (underwriting spread), for PP IPO firms. Although it is plausible that our findings may reflect successful pre-IPO private placement issuers going public, they are consistent with the general notion that pre-IPO private placements may mitigate the level of information asymmetry on the quality of issuing firms. There is also some weak support for the notion that IPO issuers may benefit from the certification of informed investors and the active monitoring role of their private placement investors. Overall, our results suggest that companies could benefit by conveying their quality via successful pre-IPO private placements that may help reduce the cost of going public.

\section{Literature Review on IPO Underpricing and Private Placement}

\section{Information Asymmetry Explanation}

A common explanation for the underpricing of equity IPOs is that it reflects the degree of information asymmetry concerning the true value of issuing firms when they go public (Rock 1986; Benveniste, Busaba, and Wilhelm 1996). Regardless of the sources of information asymmetry and the roles of different participants in the IPO process, theoretical models postulate that less underpricing is associated with IPOs that are subject to a lesser degree of information asymmetry.

Hertzel and Smith (1993) show that private placements can mitigate the level of information asymmetry concerning firm quality and value. Recent studies that examine the choice of issuance methods show that quality firms experiencing a greater degree of information asymmetry tend to use private placements over public offerings in raising external capital to reduce the costs of adverse selection and information production (Maksimovic and Pichler 2006). Sharpe and Woo (2005) find that the likelihood of using private placements increases with the degree of information asymmetry and the reputation of privately held firms.

These studies suggest that private placement is chosen as an effective issuance method to mitigate the information asymmetry regarding the quality of the issuing firm. To the extent that private placement serves the same function of reducing information asymmetry concerning privately held firms, the information asymmetry hypothesis predicts the following. 
Hypothesis 1: At the time of their IPOs, PP IPO issuers may face similar or lesser degree of information asymmetry and hence be less underpriced than their peers.

\section{Certification Explanation}

Hertzel and Smith (1993) postulate that private placements allow management of the issuing firm to put intensive effort into communicating with and convincing a concentrated group of institutional and knowledgeable individual investors of their firm quality. The information asymmetry literature suggests that some investors have better access to proprietary information than other investors (Wruck and Wu 2009). Hence, the relationship of the private placement investor to the issuing firm provides a signal or certification of firm quality: the stronger the relationship, the higher the quality of the firm. Following Wruck and $\mathrm{Wu}$ (2009), we define managers, strategic alliance partners, and existing large shareholders as informed investors, and other investors as uninformed investors. The certification explanation postulates that the willingness of informed investors, who have proprietary information about the firm, to participate in the pre-IPO private placements conveys a signal or certification of the quality of the issuing firm. Thus, we propose the following hypothesis.

Hypothesis 2: At the time of IPOs, PP IPO issuers that have informed private placement investors are associated with less underpricing.

\section{Monitoring Explanation}

The agency literature shows that private placements could be motivated by the intention to increase monitoring of management via increased ownership concentration. Shleifer and Vishny (1986) show that concentrated ownership, which is attained when a large percentage of shares is sold to a small number of investors such as the case in a private placement, improves monitoring incentives of shareholders. Hence, private placements could improve monitoring of the management of the issuing firm (Wruck 1989), especially if the ownership is concentrated among active monitoring investors (Wu 2004). Following Wu (2004), we assume that pension fund and venture capital (VC) fund investors are likely to play an active monitoring role among private placement investors and define them as the monitoring investors. If these investors are actively involved in the monitoring processes, we propose the following hypothesis.

Hypothesis 3: At the time of IPOs, PP IPO issuers that have active monitoring private placement investors are associated with less underpricing.

\section{Sample Selection and Description}

We start our sample construction with all IPOs from 1981 to 2002 reported in Thomson Financial Security Data Corporation's (SDC) New Issues Database. To allow for a homogenous sample, we exclude closed-end funds, real estate investment trusts, banks, 
nondepository financial institutions, and American Depositary Receipts. We also eliminate unit offers as well as offers with issue price less than $\$ 5$. Then, we identify pre-IPO private placement activities by checking the private placement file of the SDC New Issues Database. We match the private placement and IPO databases by the first six digits of each company's CUSIP. We define an IPO as a PP IPO if there is at least one successful private placement of equity identified for the issuing firm before its IPO.

For each IPO, the underpricing is defined as the percentage change between the offer price and the first-day closing price. The first-day closing price is obtained from the Center for Research in Securities Prices (CRSP) data file. We obtain financial statement data from Compustat data file. For each issuing firm, we identify the lead underwriter from SDC and assign an underwriter rank using Loughran and Ritter's (2004) ranking. ${ }^{1}$

Our final PP IPO sample includes 500 firms for 1981 to 2002. In Panel A of Table 1, we report the number, average issue size, and total issue volume of PP IPOs for the entire sample period. Consistent with Loughran and Ritter (2004), the average issue size increased from $\$ 50.03$ million in the 1980 s to $\$ 92.79$ million in the $1990 \mathrm{~s}$, and then \$203.71 million during the Internet bubble period, 1999-2000, before decreasing to \$99.04 million in 2001 and 2002.

Panel B of Table 1 reports the issue and firm characteristics of the PP IPOs sample and the comparison sample, which includes 6010 IPOs of issuing firms that have no prior private placements. When compared to the comparison sample, PP IPOs are larger in issue size and are offered by older firms. In addition, a larger percentage of their IPOs are underwritten by reputable underwriters. The proportion of high-tech firms, which are defined as in Loughran and Ritter (2004), ${ }^{2}$ in the PP IPOs sample is similar to that in the comparison sample.

\section{Empirical Results}

\section{Univariate Analysis of First-Day Returns (Underpricing)}

To address potential biases that may result from the differences in firm and issue characteristics of PP IPOs and the comparison sample as reported in Panel B of Table 1, we construct a matched sample of IPOs (matched sample) in which we match each PP IPO in our sample to an IPO from the comparison sample, which is of similar issue size, offered around the same time, and from the same industry.

Specifically, to form the matched sample, for each PP IPO we pick an IPO in the comparison sample whose offer date is within two months of the PP IPO's offer date. From this group, we pick the IPO that is in the same industry as the PP IPO. Next, we

\footnotetext{
${ }^{1}$ Loughran and Ritter's (2004) underwriter prestige rankings are on a scale of 0 to 9 and are based on the pecking order that is present in "tombstone" advertisements.

${ }^{2}$ As defined in Loughran and Ritter (2004), high-tech industry are those have SIC codes 3571, 3572, 3575 , 3577, 3578 (computer hardware); 3661, 3663, 3669 (communications equipment); 3674 (electronics); 3812 (navigation equipment); 3823, 3825, 3826, 3827, 3829 (measuring and controlling devices); 3841, 3845 (medical instruments); 4812, 4813 (telephone equipment); 4899 (communications services); and 7370, 7371, 7372, 7373, $7374,7375,7378,7379$ (software).
} 
TABLE 1. PP IPO Sample.

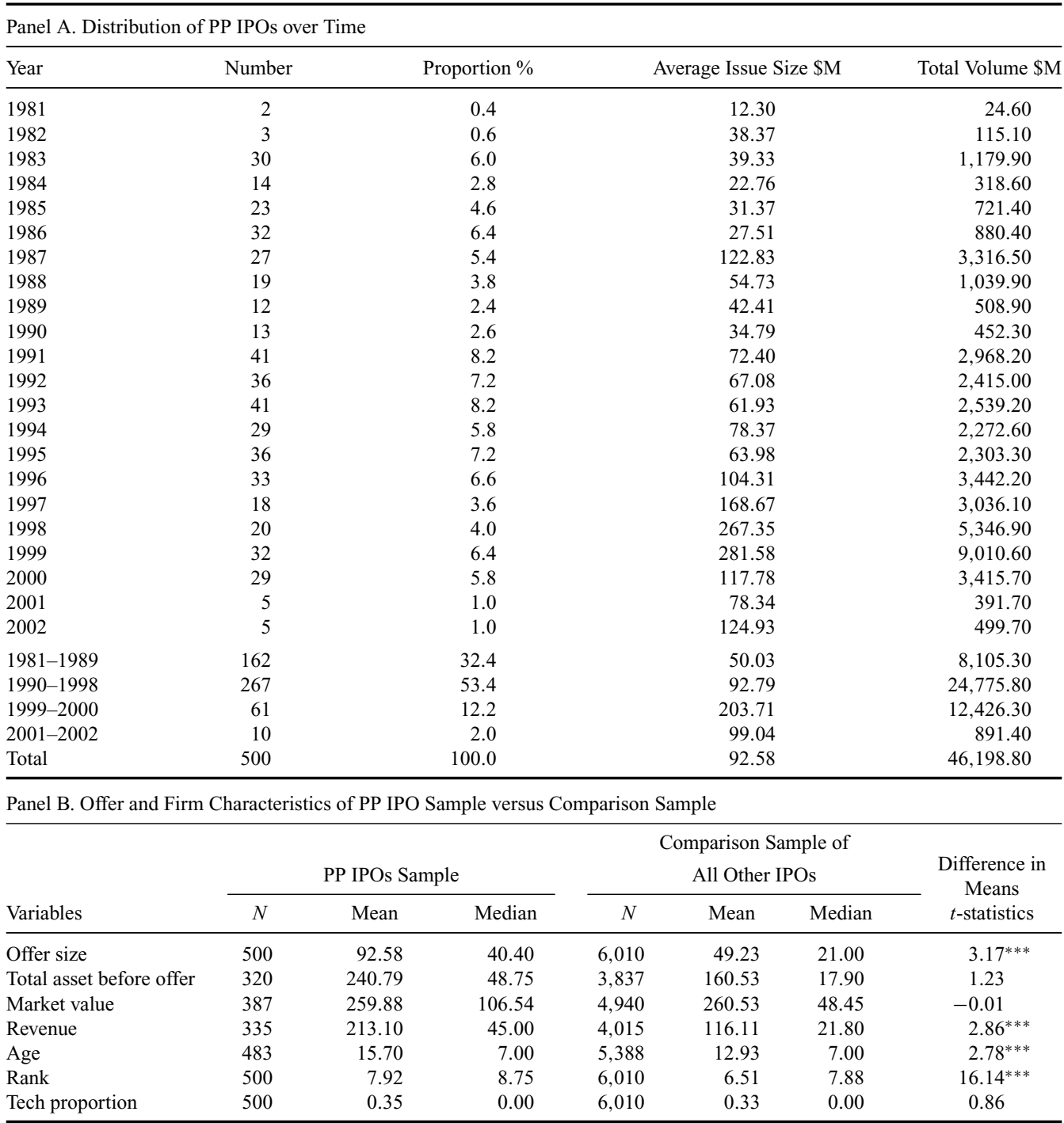

Note: PP IPOs are initial public offerings by 500 U.S. firms, each of which had at least one private placement of equity before its IPO. Panel A presents the number of PP IPOs, average issue size, and total issue volume by year. Panel B compares the offer and firm characteristics of PP IPO sample and comparison sample. Offer size is the total gross proceeds (\$ million) from the issue. Total asset (\$ million) is the value of firm's total asset at the fiscal year-end preceding its IPO. Market value (\$ million) is the market value of the firm before its IPO. It is calculated by using the number of shares before the IPO times the midpoint of the filing price range. Revenue ( $\$$ million) is the net sales for the fiscal year preceding its IPO. Age is the number of years between the firm's equity IPO and its incorporation. Rank is the underwriter rank based on Loughran and Ritter (2004). Tech dummy equals one if the firm belongs to the high-tech industry, and zero otherwise. The $t$-statistic tests whether the mean values of the variables or of the percentages of the sample where relevant are significantly different between PP IPO sample and the comparison sample.

*** Significant at the $1 \%$ level. 
TABLE 2. Univariate Comparison of Underpricing between PP IPOs and Comparison IPOs.

Panel A. Comparison by Period

\begin{tabular}{|c|c|c|c|c|}
\hline & Proportion \% & $\begin{array}{c}\text { PP IPOs Sample } \\
\text { First-Day Return \% }\end{array}$ & $\begin{array}{c}\text { Matched Sample } \\
\text { First-Day Return \% }\end{array}$ & $\begin{array}{c}\text { Difference in Means } \\
t \text {-statistics }\end{array}$ \\
\hline 1981-1989 & 32 & 6.02 & 9.64 & $-2.30^{* *}$ \\
\hline 1990-1998 & 55 & 9.74 & 14.84 & $-3.01^{* * *}$ \\
\hline 1999-2000 & 13 & 53.07 & 83.05 & $-1.98^{* *}$ \\
\hline Total & 100 & 14.30 & 22.24 & $-3.02^{* * *}$ \\
\hline \multicolumn{5}{|c|}{ Panel B. Comparison by Underwriter Prestige } \\
\hline High prestige & 76 & 14.47 & 23.49 & $-2.89^{* * *}$ \\
\hline Low prestige & 24 & 13.78 & 18.20 & -0.95 \\
\hline Total & 100 & 14.30 & 22.24 & $-3.02^{* * *}$ \\
\hline \multicolumn{5}{|c|}{ Panel C. Comparison by Time Lag between Private Placement and IPO } \\
\hline Below median & 50 & 16.31 & 25.47 & $-2.28^{* *}$ \\
\hline Above median & 50 & 11.22 & 19.09 & $-2.74^{* * *}$ \\
\hline Total & 100 & 14.30 & 22.24 & $-3.02^{* * *}$ \\
\hline
\end{tabular}

Note: In all panels of Table 2, underpricing is the percentage change from the offer price to the closing price on the first day of trade. In Panel B, for both samples, we obtain underwriter information from the Securities Data Corporation New Issues Database. High-prestige underwriters are those with Loughran and Ritter (2004) ranking of 8 or higher on a 9-point scale. In Panel C, "Below median" is defined as private placement initial public offerings (PP IPOs) that have a prior private placement within 542 days median of the period between private placement and IPO. The $t$-statistics under the column titled "Difference in Means" is the $t$-statistic associated with a difference in means test. In this means test, the null hypothesis is that the first-day returns are equal across the PP IPOs and matched samples.

*** Significant at the $1 \%$ level.

** Significant at the the $5 \%$ level.

choose the IPO whose issue size is within $50 \%$ to $150 \%$ of that of the PP IPO. The formation of the matched sample assumes, ceteris paribus, that regular IPOs are more likely to have the same underpricing behavior if they are similar in issue size, in the same industry and are offered under comparable market conditions to PP IPOs. We find matched firms for 452 (out of 500) PP IPOs. ${ }^{3}$

By Period. In Table 2, we report the means of the first-day returns (underpricing) for the PP IPOs sample and the matched sample. Panel A reports comparisons for the entire sample period and for three subsample periods: 1981-1989, 1990-1998, and 1999-2000. ${ }^{4}$ For the entire sample period, the underpricing of PP IPOs averaged $14.30 \%$, compared to $22.24 \%$ for matched IPOs. This difference is statistically significant. For both samples, underpricing increased substantially in 1999-2000. For the matched sample, the average first-day return was $9.64 \%$ in the 1980 s. In the 1990 s, the average first-day return

\footnotetext{
${ }^{3}$ Our matching criteria are motivated by the differences across the two groups that are documented in Panel B of Table 1. We do not find appropriate matches for some PP IPOs, and hence our total sample size is reduced from 500 to 452 issues. There is no match firm for 10 PP IPOs that were issued in 2001 and 2002.

${ }^{4}$ Several studies (e.g., Loughran and Ritter 2004) document unusual pattern in IPO underpricing during the Internet bubble period. Therefore, we redo our empirical tests excluding IPOs during the period of 1999-2002. The main results are qualitatively identical to those reported in this article.
} 
increased to $14.84 \%$, then jumped to more than $83.05 \%$ during the Internet bubble period. A similar pattern is observed for the PP IPOs sample. In the 1980s, the average first-day return was $6.02 \%$. In the $1990 \mathrm{~s}$, the average first-day return rose to $9.74 \%$ and then increased to $53.07 \%$ during the Internet bubble period. In all subsample periods, the initial returns for PP IPOs are significantly (at the 5\% level) lower than the respective levels for the matched sample.

By Underwriter Reputation. In Panel B of Table 2, we categorize IPOs on the basis of the reputation of their lead underwriters. We define high-prestige underwriters (HPUs) as those with a Ritter and Loughran (2004) ranking of 8 or higher on a 9point scale. We note that more than three-fourths of the PP IPOs are led by HPUs. The results show that PP IPOs underwritten by HPUs experienced average initial returns of $14.47 \%$ compared to $13.78 \%$ for those managed by less prestigious underwriters (LPUs). The returns are $23.49 \%$ and $18.20 \%$ for the matched sample, respectively. We find that the underpricing of the PP IPOs sample is significantly less than that of the matched sample for issues underwritten by HPUs. For issues that were underwritten by LPUs, the underpricing of PP IPOs is not significantly less than that of the matched sample.

By Time Lag between Private Placement and IPO. In Panel C of Table 2, we examine whether the time lag between the private placement and the IPO affects IPO underpricing. For our PP IPOs sample, the mean and median time lags are 2.5 and 1.5 years respectively. We divide the PP IPOs into two groups by the median time lag (542 days) in Panel C. The results show that both groups of PP IPOs have significantly less underpricing than the matched firms. We also note that PP IPOs that go public sooner following their private placements experienced marginally significantly more underpricing than those that have longer time lags between their private placements and IPOs. However, this finding is probably driven by more PP IPO issuers in the below-median group taking advantage of the hot issue market to go public during the Internet bubble period, which is characterized as a period of unusually large underpricing.

In summary, the results reported in Table 2 suggest that PP IPOs experienced significantly less underpricing than their peers, especially those that are underwritten by reputable underwriters. These results hold across different subsample periods and regardless of the time lag between their pre-IPO private placements and their IPOs.

To supplement the analysis of underpricing in measuring the impact of pre-IPO private placements on issuance costs, we compare the gross spread of PP IPOs with that of the matched IPOs. ${ }^{5}$ We find that the average gross spread of PP IPOs was less than that of matched IPOs in each subsample period. For the entire sample period, the gross spread of PP IPOs is $7.02 \%$, which is significantly lower than that of the matched sample (7.13\%). Hence, we conclude that PP IPOs are associated with lower issuance costs than their peers.

\section{Regression Analysis of Underpricing}

Next, we examine the underpricing of PP IPOs and all other IPOs by using the ordinary least squares (OLS) regression analysis to control for known factors that may explain

\footnotetext{
${ }^{5}$ Though the results are not reported in this article, they are available from the authors upon request.
} 
their underpricing. The dependent variable is underpricing. The independent variables control for demand for issue, firm and issue sizes, industry, market conditions, and firm quality.

PP Dummy and Control Variables. The PP dummy is a binary variable that equals one if the issuer had pre-IPO private placements, and zero otherwise. This dummy variable captures the difference in underpricing between issuing firms that had prior private placements and those that did not in a multivariate regression setting.

$M K T V$ is defined as the logarithm of the value (in \$million) of the issuing firm before its IPO, where the value is calculated by multiplying the number of shares before the IPO with the midpoint of the filing price range.

Chemmanur and Paeglis (2005) find that IPOs that are certified by managerial quality of the issuer are associated with larger issue sizes. They argue that the larger issue size reflects a larger scale of value creating investment projects. We define Offer_Size as the natural logarithm of the IPO issue size (in \$million). The market probably knows more about older firms through their products even though their securities may not have a public presence. We measure firm age (Age) by the number of years between their year of incorporation and the year of their IPO.

We use three variables to control for market conditions at the time of the IPO: (1) MKTret, which we define as the average return on the CRSP value-weighted index over the period between the filing date and the offer date; (2) $S D \_M K T$, which we define as standard deviation of the market return between the filing date and the offer date; and (3) IPOVol, which we define as the number of IPOs offered during the six weeks before the IPO offer date.

Beatty and Welch (1996) document a nonstationary relation between reputation and underpricing. To control for the role of underwriter's reputation in certifying the quality of the issuing firm, we include the underwriter rank of Loughran and Ritter (2004) as the Rank variable. The literature documents unusual IPO underpricing pattern during the Internet bubble period. Hence, we include the Tech and Internet dummy variables to control for their impacts on underpricing. The Tech dummy equals one if the issuing firm belongs to the high-tech industry as defined earlier, and zero otherwise. The Internet dummy equals one if the issue occurred during 1999-2000, and zero otherwise.

As new information about the demand for the IPO becomes available through the road show for an IPO, underwriters tend to revise the offer price. We include the Scaled_Offer variable, which is defined by scaling the IPO offer price by the average of the original high and low filing prices, $P_{H i g h}$ and $P_{\text {Low }}$, to control for this effect. We also include the Upward variable in the regressions. Upward equals one if the offer price is set above the initial filing price range, and zero otherwise.

Regression Results. Consistent with the overall results of the univariate analysis, Model 1 of Table 3 reports a significant negative coefficient for the PP dummy. This suggests that issuers that have pre-IPO private placements experience less underpricing than those without, and the observed less underpricing of PP IPO firms cannot be explained by the control variables that are used in the regression.

Consistent with Ljungavist (2007), the significant negative coefficients for offer size and firm age variables reflect that issuing firms that are perceived to be of better quality are subject to less underpricing. Technology firms tend to have more underpricing. 
TABLE 3. Regressions.

\begin{tabular}{|c|c|c|c|c|}
\hline & \multicolumn{2}{|c|}{ Model 1} & \multicolumn{2}{|c|}{ Model 2} \\
\hline & Coefficient & $t$-statistics & Coefficient & $t$-statistics \\
\hline \multicolumn{5}{|c|}{ Panel A. OLS Regressions on IPO Underpricing } \\
\hline Constant & 11.953 & $2.98^{* * *}$ & 11.429 & $3.07^{* * *}$ \\
\hline$P P$ dummy & -4.128 & $-2.03^{* *}$ & -5.056 & $-2.72^{* * *}$ \\
\hline MKTret & 2.758 & 0.60 & 7.633 & $1.81^{*}$ \\
\hline$S D \_M K T$ & 0.002 & 0.45 & 0.002 & 0.56 \\
\hline IPOVol & -1.151 & -1.38 & -1.107 & -1.45 \\
\hline$M K T V$ & 5.277 & $6.85^{* * *}$ & 4.923 & $7.00^{* * *}$ \\
\hline Offer_Size & -6.567 & $-6.36^{* * *}$ & -4.686 & $-4.96^{* * *}$ \\
\hline Age & -0.095 & $-2.91^{* * *}$ & -0.101 & $-3.41^{* * *}$ \\
\hline Tech & 4.689 & $3.74^{* * *}$ & 3.646 & $2.91^{* * *}$ \\
\hline Internet_Tech & & & 8.721 & $2.90^{* * *}$ \\
\hline Internet & 39.657 & $22.16^{* * *}$ & -29.572 & $-3.64^{* * *}$ \\
\hline Scaled_Offer & 7.322 & $20.17^{* * *}$ & 3.447 & $9.17^{* * *}$ \\
\hline Internet_Scaled & & & 12.385 & $15.86^{* * *}$ \\
\hline Upward Revision & 16.885 & $9.04^{* * *}$ & 12.729 & $6.78^{* * *}$ \\
\hline Interent_Upward & & & 13.761 & $3.07^{* * *}$ \\
\hline Rank & 0.483 & 1.31 & -0.183 & -0.53 \\
\hline Internet_Rank & & & 6.252 & $6.35^{* * *}$ \\
\hline Adj. $R^{2}$ & & 0.40 & & 0.50 \\
\hline No. of obs. & & 3,947 & & 3,947 \\
\hline \multicolumn{5}{|c|}{ Panel B. OLS Regressions on Underpricing for Non-VC-Backed IPOs } \\
\hline Constant & 6.352 & $2.29^{* *}$ & 7.990 & $2.90^{* * *}$ \\
\hline$P P$ dummy & -3.387 & $-2.06^{* *}$ & -3.208 & $-1.97^{* *}$ \\
\hline MKTret & 12.863 & $4.44^{* * *}$ & 13.717 & $4.79^{* * *}$ \\
\hline$S D \_M K T$ & 0.002 & 1.21 & 0.002 & 1.27 \\
\hline IPOVol & 1.198 & $1.82 *$ & 1.177 & $1.81^{*}$ \\
\hline MKTV & 0.385 & 0.82 & 0.423 & 0.91 \\
\hline Offer_Size & -0.367 & -0.60 & -0.354 & -0.58 \\
\hline Age & -0.056 & $-3.11^{* * *}$ & -0.056 & $-3.18^{* * *}$ \\
\hline Tech & 4.960 & $5.45^{* * *}$ & 3.650 & $3.81^{* * *}$ \\
\hline Internet_Tech & & & 10.277 & $3.80^{* * *}$ \\
\hline Internet & 11.385 & $8.16^{* * *}$ & -18.672 & $-3.50^{* * *}$ \\
\hline Scaled_Offer & 3.040 & $12.02^{* * *}$ & 2.814 & $10.52^{* * *}$ \\
\hline Internet_Scaled & & & 1.427 & $1.96^{* *}$ \\
\hline Upward Revision & 12.170 & $9.63^{* * *}$ & 11.738 & $8.82^{* * *}$ \\
\hline Interent_Upward & & & 1.154 & 0.29 \\
\hline Rank & -0.282 & -1.28 & -0.513 & $-2.31^{* *}$ \\
\hline Internet_Rank & & & 3.317 & $4.98^{* * *}$ \\
\hline Adj. $R^{2}$ & & 0.29 & & 0.31 \\
\hline No. of obs. & & 2,131 & & 2,131 \\
\hline
\end{tabular}

Note: The dependent variable is the initial return. The $P P$ dummy is a dummy variable that equals one if the issue is a private placement initial publication offering (PP IPO), and zero otherwise. MKTret is the market return on the CRSP value-weighted index between the offer and the filing date of the IPO. $S D \_M K T$ is the standard deviation of the market return over the time between the filing and the offer date. IPOVol is the number of IPOs during the six weeks before the IPO offer date. MKTV is the logarithm of the market value of the firm in millions of dollars before its IPO. It is calculated by using the number of shares before the filing times the midpoint of the filing price range. Offer_Size is the natural logarithm of the IPO issue size. Age is the difference in the number of years between their year of incorporation and the year of their IPO. Tech is the high-tech industry dummy that equals one if the firm belongs to the high-tech industry, and zero otherwise. Internet is the Internet bubble dummy that equals one if the issue occurred during 1999-2000, and zero otherwise. Scaled_Offer is defined by scaling the IPO offer price by the average of the original high and low filing prices, $P_{\text {High }}$ and $P_{\text {Low }}$. Upward equals one if Revision is greater than one, and zero otherwise. Rank is the underwriter rank based on Loughran and Ritter (2004). Internet_XXX is the interaction of Internet dummies and the variable $X X X$. For example, Internet_Rank is the interaction of rank and Internet dummies. OLS $=$ ordinary least squares; $\mathrm{VC}=$ venture capital.

${ }^{* * *}$ Significant at the $1 \%$ level.

** Significant at the $5 \%$ level.

*Significant at the $10 \%$ level. 
The Internet dummy is positive and significant, reflecting greater underpricing during the Internet bubble years of 1999-2000. In addition, the positive and highly statistically significant coefficients for the Scaled_Offer and Upward variables that reflect strong demand for the issues are associated with greater underpricing.

On the other hand, the positive though statistically insignificant coefficient for the Rank dummy variable suggests that more underpricing is associated with quality issuers that are underwritten by reputable underwriters. This result is inconsistent with the implications of the certifying roles of reputable underwriters. However, Loughran and Ritter (2004) argue that changing underwriting practices might explain the increasing IPO underpricing over time, especially during the Internet bubble period.

Further Regression Results. In our further analysis of the role of pre-IPO private placements in lesser underpricing, we control for the impacts of changing underwriting practices on IPO underpricing during the Internet bubble period by introducing interactive variables on selected control variables. Loughran and Ritter (2004) suggest that the relaxation of standards by reputable underwriters resulted in their taking public an increasing number of young unprofitable companies. This may explain the unusual IPO pricing patterns observed for the Internet bubble period. Hence, we introduce the interactive dummy variable, Internet_Rank, to capture IPOs that were underwritten by reputable underwriters during the Internet bubble period. In Model 2, the positive and significant (at the 1\% level) coefficient for the Internet_Rank dummy is consistent with the explanations provided by Loughran and Ritter for changing underpricing patterns during the Internet bubble period. ${ }^{6}$

In addition, we add interactive variables to the Tech dummy, Scaled_Offer and Upward variables, that is, Internet_Tech, Internet_Scaled, and Internet_Upward, respectively, to capture their potential differential impacts on IPO underpricing during the Internet bubble period. The positive and significant coefficients for these interactive variables are consistent with the unusual underpricing patterns documented for the Internet bubble period in the literature. ${ }^{7}$

More important, the coefficient for the $P P$ dummy variable continues to be negative and significant (at the 1\% level) in Model 2 further supports the role of pre-IPO private placements in reducing underpricing of the issuing firms at the time of their IPOs.

The negative and significant coefficients of the $P P$ dummy in both models suggest that even after we control for relevant factors that are known to affect IPO underpricing in a multivariate framework, the results from the univariate analyses remain

\footnotetext{
${ }^{6}$ Fernando, Gatchev, and Spindt (2005) show that issuing firms and underwriters make mutual decisions in pairing themselves up, and that underwriter reputation and issuer quality are complementary, in the IPO process. In other words, prestigious investment bankers choose to underwrite better quality firms, and better quality firms tend to choose more reputable underwriters, supporting the notion that underwriter serves as a certifying agent for the issuer's quality. By hiring reputable underwriters, better quality issuers convey a positive signal to investors and experience less underpricing (Safieddine, McLaughlin, and Vasudevan 2000). With the existence of endogeneity between firm quality and underwriter choice, the OLS coefficients of explanatory variables may be inconsistent.

${ }^{7}$ It is interesting to note the significant negative coefficient for the Internet dummy variable in model 2, which suggests that unpopular IPOs of nontech firms experienced significantly less underpricing during the Internet bubble period.
} 
robust. Private placement activities of issuing firms prior to their IPOs are associated with lesser underpricing of their IPOs.

\section{Robustness Test}

The literature documents conflicting impacts of VC backing on the underpricing of IPOs. Earlier studies such as Megginson and Weiss (1991) show that VC backing reduces IPO underpricing. On the other hand, Lee and Wahal (2004) and Loughran and Ritter (2004) show that IPOs backed by VC are associated with greater underpricing, especially during the Internet bubble period. Furthermore, Ritter (2009) documents that VC-backed IPOs continue to experience larger underpricing than IPOs that are not $\mathrm{VC}$ backed in the post-Internet bubble era.

To the extent that our sample and matched IPOs are backed by VC, our results may be distorted by the documented impacts of VC backing on IPO underpricing. Hence, we check the robustness of our findings of significantly less underpricing of PP IPOs by filtering out VC-backed IPOs, which are identified using the SDC database, from our analysis.

We report the results on the smaller, uncontaminated sample of 195 PP IPOs that are not backed by VC. The univariate results show that the average underpricing of these 195 non-VC-backed IPOs is $13.65 \%$, compared to $23.41 \%$ for their matched sample of non-VC-backed IPOs. The difference is statistically significant at the 5\% level $(t=-2.27)$. In addition, Panel $\mathrm{B}$ of Table 3 reports the regression analysis on the underpricing of the non-VC-backed PP IPOs and all other non-VC-backed IPOs after controlling for known factors that may explain their underpricing. Using the same model specifications as in Panel A of Table 3, we find negative and statistically significant coefficients for the $P P$ dummy in both regressions. These findings suggest that our results regarding the mitigating effect of pre-IPO private placements on IPO underpricing are not driven by VC-backed IPOs.

\section{Potential Explanations for Less Underpricing of PP IPOs}

The findings on first-day returns suggest that PP IPOs are not subject to higher underpricing than their peers. Furthermore, after we control for known factors that determine IPO underpricing, PP IPOs face significantly less underpricing. In this section, we try to explain why PP IPOs experience less under pricing.

\section{Information Asymmetry Explanation}

In Table 4, we use professional analysts' coverage as a proxy for information asymmetry concerning the quality of the issuing firm. We present data on analyst coverage for PP IPOs and the matched sample from the Institutional Broker Estimates System (IBES) database. Previous studies use analyst coverage to measure the level of information available to the market and investors. For instance, Chang, Dasgupta, and Hilary (2006) argue for a negative correlation between the level of analyst coverage and the degree of information asymmetry faced by issuing firms. Such an inverse relation may result from 
TABLE 4. Analysts' Coverage.

\begin{tabular}{lccc}
\hline & PP IPOs & Matched Sample & $t$-statistics \\
\hline Number of analysts -2 months of IPO & 2.56 & 2.25 & $1.83^{*}$ \\
Number of analysts -6 months of IPO & 3.09 & 2.94 & 1.05 \\
IPOs with coverage in $<2$ month \% & 40.71 & 39.38 & 0.58 \\
IPOs with coverage in $<6$ months \% & 76.33 & 71.90 & $2.09^{* *}$ \\
\hline
\end{tabular}

Note: This table reports data on analysts' coverage for private placement initial public offerings (PP IPOs) and matched sample from Institutional Broker Estimates System (IBES) database. The $t$-statistic is the difference of means $t$-test.

** Significant at the $5 \%$ level.

* Significant at the $10 \%$ level.

analysts' ability to directly reduce information asymmetry, or analysts being attracted to firms that face a lesser degree of information asymmetry, which lowers the information acquisition costs. Because there is no analyst coverage of the issuing firm preceding its IPO, we assume that postissue analyst coverage is positively correlated with information availability at the time of the IPO. A different strand of the literature, however, suggests that IPO firms may purchase analyst coverage with underpricing (Cliff and Dennis 2004). Rajan and Servaes (1997) and Loughran and Ritter (2004) find that IPO underpricing is positively related to analyst coverage, especially during the Internet bubble period.

The results in Table 4 show that even with less underpricing than the matched sample, PP IPO firms enjoy significantly (at the 10\% level) more analyst coverage two months (about the expiration date of the quiet period) after their IPOs. In addition, the percentage of the PP IPOs sample that has analyst coverage six months from their IPOs is significantly (at the 5\% level) higher than that of the matched sample. These results are consistent with the notion that issuing firms that had pre-IPO private placements may face a lesser degree of information asymmetry concerning their quality than their peers at the time of their IPOs. ${ }^{8}$ Therefore, even with lower underpricing, these firms attract more analyst coverage.

In the theoretical models that are discussed in Section I, underpricing is considered as a measure of information asymmetry. Firms for which information is more readily available and transparent are expected to be associated with less underpricing at the time of their IPOs. Older firms are more likely to be associated with greater information availability because they are likely to be more established and better known to investors, and hence subject to less information asymmetry. Although the results in Table 5 show that there is no significant difference between the age of the PP IPOs and the matched sample at the time of their IPOs, Panel B of Table 1 shows that PP IPO issuers are older than other IPO issuers who had no pre-IPO private placement activities.

The Securities and Exchange Commission (SEC) requires firms to file financial information starting the year of their public debt or equity offering. Privately held firms must file with the SEC if they have 500 or more employees. PP IPO issuers could be

\footnotetext{
${ }^{8}$ Our results are consistent with McNichols and O'Brien's (1997) postulation that the optimistic bias in analysts' coverage is a result of their selective allocation of scarce resources to cover quality firms.
} 
TABLE 5. Age and Proportion of Firms that Have Information on Compustat Database One Year before the Time of the Equity IPO.

\begin{tabular}{lccc}
\hline & PP IPOs Sample & Matched Sample & $\begin{array}{c}t \text {-statistics } \\
\text { of Difference }\end{array}$ \\
\hline $\begin{array}{l}\text { Age } \\
\text { Mean } \\
\text { Median }\end{array}$ & 15.70 & 15.39 & 0.05 \\
& 7 & 7 & Comparison across \\
& PP IPOs Sample & Matched Sample & Groups \\
\hline $\begin{array}{l}\text { \% of Firms that Have Information on } \\
\text { Compustat One Year Before the }\end{array}$ & & & $t$-statistics \\
Firm's Equity IPO & Proportion \% & Proportion \% & 1.64 \\
Information on total assets & 33.85 & 30.31 & 1.64 \\
Information on sales & 33.63 & 30.09 & \\
\hline
\end{tabular}

Note: Age is the difference in the number of years between their year of incorporation and the year of their initial public offering (IPO). The $t$-statistic is a difference of means $t$-test that tests differences across the two groups.

better known to the investment community by virtue of their pre-IPO private placements. Therefore, we examine the history of publicly available information on the issuing firms at the time of their IPOs by searching the Compustat database for firms that have information one year before their IPOs. We find that almost $34 \%$ of PP IPOs, compared to $30 \%$ for the matched sample, have information on Compustat one year before their IPOs. However, the difference is marginally significant at the $11 \%$ level.

Overall, these findings, albeit weak, are consistent with the postulation of the information asymmetry explanation that successful pre-IPO private placements help mitigate information asymmetry concerning the quality of issuing firms that lead to less underpricing at their IPOs.

\section{Certification Explanation}

Since May 1996, firms are required to file prospectuses for their private placements electronically with the SEC. In our sample, there are 135 PP IPOs offered after May 1996. For these 135 PP IPOs, we search the SEC's EDGAR database for complete prospectuses (S-1) with keywords such as private stock offering, private placement, privately negotiated transaction, and direct placement (sale). We then identify names and characteristics of the investor(s), and their relationships with the issuing firm from the "Management" and "Principal and Selling Shareholders" sections of the IPO prospectus. In addition, we supplement our search with the news file of the LexisNexis database and the issuing company's website. Overall, we find private placement investor information for 130 of these 135 companies.

We follow $\mathrm{Wu}(2004)$ to categorize private placement investors into seven nonexclusive groups: (1) managers (officers and directors), (2) strategic alliance partners (suppliers, customers, and strategic alliance partners), (3) existing large shareholders (existing shareholders with at least 5\% ownership), (4) VC firms, (5) financial institutions (pension funds, insurance companies, mutual funds, banks, foundations, units and investment 
TABLE 6. Private Placement Investors.

\begin{tabular}{lcc}
\hline & Number of Placements & Frequency $\%$ \\
\hline Managers & 22 & $16.30 \%$ \\
Strategic alliance partners & 29 & $21.48 \%$ \\
Existing large shareholders & 19 & $14.07 \%$ \\
Venture capital firms & 39 & $28.89 \%$ \\
Financial institutions & 67 & $49.63 \%$ \\
Corporate investors & 13 & $9.63 \%$ \\
Individual investors & 13 & $9.63 \%$ \\
Characteristics of investors unidentified & 5 & $3.70 \%$ \\
Multiple investors & 41 & $30.37 \%$ \\
Single investor & 89 & $65.93 \%$ \\
Number of investors unidentified & 5 & $3.70 \%$ \\
\hline
\end{tabular}

Note: This table presents the number and frequency of pre-IPO private placements that were placed with the respective categories of investors as defined in $\mathrm{Wu}(2004)$.

TABLE 7. Univariate Comparison of Underpricing by Pre-IPO Private Placement Investors' Types.

\begin{tabular}{|c|c|c|c|c|}
\hline & Proportion \% & $\begin{array}{c}\text { PP IPOs Sample } \\
\text { First-Day Return \% }\end{array}$ & $\begin{array}{c}\text { Matched Sample } \\
\text { First-Day Return \% }\end{array}$ & $\begin{array}{c}\text { Difference in Means } \\
t \text {-statistics }\end{array}$ \\
\hline \multicolumn{5}{|c|}{ Panel A. Whether Private Placement Investors Are Informed } \\
\hline Uninformed & 58 & 34.44 & 55.98 & $-1.84^{*}$ \\
\hline Informed & 42 & 24.71 & 51.52 & $-2.51^{* *}$ \\
\hline Total & 100 & 31.04 & 55.30 & $-2.91^{* * *}$ \\
\hline \multicolumn{5}{|c|}{ Panel B. Whether Private Placement Investors are Monitoring } \\
\hline Passive group & 61 & 32.81 & 49.51 & -1.58 \\
\hline Active monitoring group & 39 & 28.31 & 63.10 & $-2.56^{* *}$ \\
\hline Total & 100 & 31.04 & 55.30 & $-2.91^{* * *}$ \\
\hline
\end{tabular}

Note: Underpricing is the percentage change from the offer price to the closing price on the first day of trade. The $t$-statistics under the column titled "Difference in Means" is the $t$-statistic associated with a difference in means test. In this means test, the null hypothesis is that the first-day returns are equal across the private placement initial public offerings (PP IPOs) and matched samples. In Panel A, "Informed" is defined as the first three groups: (1) managers, (2) strategic alliance partners, and (3) existing large shareholders. In Panel B, "Active monitoring group" is defined as the private placement investors who are pension funds and venture capitalists who actively monitor the issuers.

*** Significant at the $1 \%$ level.

** Significant at the $5 \%$ level.

* Significant at the $10 \%$ level.

trusts, and endowments), (6) corporate investors with no business ties to the issuing firm, and (7) Individual investors with no employment or business ties to the issuing firm.

Table 6 reports that approximately half of the pre-IPO private placements of equity of these 130 PP IPO issuers are placed with financial institutions, followed by venture capitalists (29\%) and strategic alliance partners (21.5\%). Besides, about $30 \%$ of private placements are placed with multiple investors.

In Panel A of Table 7, we categorize private placement investors on the basis of information they have. Following Wruck and Wu (2009), we define the first three groups of private placement investors, namely, managers, strategic alliance partners, and 
existing large shareholders, to be informed investors (Informed), and other investors as uninformed investors (Uninformed). The willingness of sophisticated investors, who have proprietary information about the firm, to participate in the pre-IPO private placements conveys a signal or certification of the quality of the issuing firm. The results show that the underpricing of PP IPOs is significantly less than that of the matched sample, regardless of the types of private placement investors. Although PP IPOs with informed private placement investors experienced less underpricing than PP IPOs with uninformed private placement investors $(24.71 \%$ vs. $34.44 \%)$, the difference is not statistically significant. Besides, the magnitude of the difference in underpricing of PP IPOs with informed investors and that of their matched IPO peers $(26.81 \%)$ is comparable to the magnitude of underpricing for the PP IPOs with uninformed investors sample (21.54\%). Hence, the support for the certification explanation (Hypothesis 2) is limited.

\section{Monitoring Explanation}

In Panel B of Table 7, we categorize private placement investors on the basis of whether they actively monitor the firm. We follow Wu (2004) and define pension funds and venture capitalists as private placement investors who actively monitor the issuers. Pension fund managers actively monitor their portfolio companies through participation in proxy proposals, private negotiation, or both (Karpoff 2001), and venture capitalists work closely with management and hence monitor them intensively (Admati and Pfleiderer 1994). Consistent with Hypothesis 3, the results show that the IPO underpricing of the active monitoring investors group is significantly less than that of their matched firms, while the difference between IPO underpricing of the passive investors group and that of their matched firms is not statistically significant. In addition, the group of 51 PP IPOs with active private placement investors experienced less underpricing $(28.31 \%)$ than the 79 PP IPOs with passive private placement investors $(32.81 \%)$. Though not statistically significant, the magnitude of the difference in the underpricing of PP IPOs with active investors and that of their matched IPO peers $(34.79 \%)$ is more than double of the magnitude of the difference in underpricing for the PP IPOs with passive investors sample (16.70\%). Overall, our findings suggest a possible though limited role of the monitoring activities of private placement investors in improving the quality of PP IPO issuers that leads to their lesser IPO underpricing.

\section{Long-Term Stock Price Performance of PP IPO Issuers}

In this section, we explore the long-term risk-adjusted stock return performance of IPOs with prior private placements in relation to that of their peers. Following Fama (1993) and Mitchell and Stafford (2000), we use a monthly calendar-time portfolio approach to gauge the long-term abnormal performance of our PP IPOs and matched IPOs during the sample period. For each calendar month we form value-weighted portfolios for each of the PP IPOs and matched IPOs samples. The weights are based on the end of previousmonth market capitalization of sample firms. The excess returns of the portfolios are used to estimate the Fama-French three-factor model as follows:

$$
R_{p t}-R_{f t}=\alpha+\beta\left(R_{m t}-R_{f t}\right)+\gamma S M B_{t}+\delta H M L_{t}+\varepsilon_{t},
$$


TABLE 8. Long-Term Stock Price Performance of PP IPOs Relative to Matched IPO Sample.

\begin{tabular}{|c|c|c|c|c|}
\hline \multicolumn{5}{|c|}{ PP IPO Sample } \\
\hline Intercept $\alpha$ & $\beta$ & $\gamma$ & $\delta$ & Adjusted $R^{2}$ \\
\hline $\begin{array}{l}-0.03388 \\
-0.13\end{array}$ & $\begin{array}{l}1.06798 \\
(16.96)\end{array}$ & $\begin{array}{l}0.53883 \\
(6.73)\end{array}$ & $\begin{array}{l}-0.70972 \\
(-7.39)\end{array}$ & 0.7023 \\
\hline \multicolumn{5}{|c|}{ Matched IPO sample } \\
\hline $\begin{array}{l}-0.00181 \\
-0.02\end{array}$ & $\begin{array}{l}1.25416 \\
(13.09)\end{array}$ & $\begin{array}{l}0.93529 \\
(7.69)\end{array}$ & $\begin{array}{l}-0.99041 \\
(-6.77)\end{array}$ & 0.8622 \\
\hline $\begin{array}{l}\text { Difference in intercept } \\
\text { PP IPO-Other IPOs }\end{array}$ & \multicolumn{4}{|c|}{$\begin{array}{l}-0.03569 \\
(-1.28)\end{array}$} \\
\hline
\end{tabular}

Note: This table presents the Fama and French (1993) three-factor time-series regression results for three years following the initial public offering (IPO). For each calendar month we form a value-weighted portfolio for each of the private placement (PP) IPOs and matched IPOs sample. The weights are based on the end of previous-month market capitalization of sample firms. The excess returns of the portfolio are used to estimate the Fama-French three-factor model as follows:

$$
R_{p t}-R_{f t}=\alpha+\beta R_{m t}-R_{f t}+\gamma S M B_{t}+\delta H M L_{t}+\varepsilon_{t},
$$

where $R_{p t}$ is the calendar-time portfolio return for each sample in month $t$ and $R_{f t}$ is the risk-free return in the same month. The three Fama-French factors are the excess return on the market portfolio $R_{m t}-R_{f t}$, the difference in the returns of value-weighted portfolios of small stocks and large stocks, $S M B_{t}$, and the difference in returns of value-weighted portfolios of high book-to-market and low book-to-market stocks, $H M L_{t}$. The $t$-statistics for intercept is given below in parentheses.

where $R_{p t}$ is the calendar-time portfolio return for each sample in month $t$ and $R_{f t}$ is the risk-free return in the same month. The three Fama-French factors are the excess return on the market portfolio $\left(R_{m t}-R_{f t}\right)$, the difference in the returns of value-weighted portfolios of small stocks and large stocks $\left(S M B_{t}\right)$, and the difference in the returns of value-weighted portfolios of high book-to-market and low book-to-market stocks $\left(H M L_{t}\right)$. The coefficient estimate of the intercept term, $\alpha$, from the time-series regressions are used as an indicator of risk-adjusted stock return for each sample portfolio.

Table 8 presents the time-series regression results of the Fama and French (1993) three-factor model for a three-year horizon following the month of the IPO. We observe that the intercept terms for both samples of IPOs are not reliably different from zero. This is consistent with the findings of Ritter and Welch (2002) that IPOs issued between 1973 and 2001 had insignificant intercepts in Fama and French three-factor regressions. Similarly for our IPO samples, the coefficients of the market factor $\left(R_{m t}-R_{f t}\right)$ and the size factor $\left(S M B_{t}\right)$ show compatible magnitude and sign to those reported in Ritter and Welch (2002) and Brav and Gompers (1997). However, the magnitude of the book-tomarket ratio loading is larger than, even though it has the same sign as, that documented in earlier studies. Furthermore, the loadings of the market factor suggest that our PP IPO and matched IPO firms have higher than average levels of systematic risk. In addition, their returns covary with the returns of low book-to-market ratio (growth) firms. In summary, our sample IPO firms have similar characteristics as those reported in prior studies. Although we observe some differences in the factor loadings between our two samples of IPO firms, the intercept term for the PP IPOs sample $(-3.39 \%)$ is not significantly different from that of the matched IPOs sample $(-0.18 \%)$. This implies that PP IPO 
firms do not display long-term risk-adjusted stock price underperformance relative to their peers.

\section{Conclusion}

Could prior private placements of privately held firms help reduce the issuance costs (both underpricing and underwriting spread) of their IPOs? We find that PP IPO firms, that is, firms that have successful private placements of equity before their IPOs, experience less underpricing and less underwriting spread at the time of their IPOs than their peers. Our findings are consistent with the notion that PP IPO firms are able to convey their quality credibly to the market with their successful pre-IPO private placements, thus reducing the level of information asymmetry at the time of their IPOs. There is weak evidence that less underpricing of PP IPO issuers relative to their peers is more evident among those who are placed with informed investors and active monitoring investors. Although issuing firms of PP IPOs are about the same age as the matched firms, they have more information available before their IPOs and enjoy more analyst coverage than their peers.

A lower degree of information asymmetry may result in lower costs for outsiders to evaluate the IPO firms. The outsiders can be financial intermediaries evaluating the firm for their decisions to underwrite or institutional investors evaluating the firm for their decisions to invest. This can result in more reputable underwriting syndicates and lower underwriting spreads that are observed for firms that have private placements before their IPOs. On the whole, our results suggest that quality issuers could benefit by successful pre-IPO private placements that may help reduce the costs of going public.

\section{References}

Admati, A., and P. Pfleiderer, 1994, Robust financial contracting and the role of venture capitalists, Journal of Finance 49, 371-402.

Beatty, R., and I. Welch, 1996, Issuer expenses and legal liability in initial public offerings, Journal of Law \& Economics 39, 545-602.

Benveniste, L., W. Busaba, and W. Wilhelm, 1996, Price stabilization as bonding mechanism in new equity issues, Journal of Financial Economics 42, 223-55.

Brav, A., and P. Gompers, 1997, Myth or reality? The long-run underperformance of initial public offerings: Evidence from venture and nonventure capital-backed companies, Journal of Finance 52, 1791-1821.

Cai, N., L. Ramchand, and A. Warga, 2004, The pricing of equity IPOs that follow debt IPO, Financial Management 33, 3-32.

Chang, X., S. Dasgupta, and G. Hilary, 2006, Analyst coverage and financing decisions, Journal of Finance 61, $3009-47$.

Chemmanur, T., and I. Paeglis, 2005, Management quality, certification, and initial public offering, Journal of Financial Economics 76, 331-68.

Cliff, M., and D. Denis, 2004, Do IPO firms purchase analyst coverage with underpricing? Journal of Finance 59, 2871-2901.

Fama, E., and K. French, 1993, Common risk factors in the returns on stocks and bonds, Journal of Financial Economics 43, 3-56.

Fernando, C. S., V. Gatchev, and P. Spindt, 2005, Wanna dance? How firms and underwriters choose each other, Journal of Finance 60, 2437-69.

Hertzel, M., and R. Smith, 1993, Market discounts and shareholder gains for placing equity privately, Journal of Finance 48, 459-86. 
James, C., 1987, Some evidence of the uniqueness of bank loans, Journal of Financial Economics 19, $217-35$.

Karpoff, J. M., 2001, The impact of shareholder activism on targeted companies: A survey of empirical findings, Unpublished working paper, University of Washington.

Lee, P., and S. Wahal, 2004, Grandstanding, certification and the underpricing of venture capital backed IPOs, Journal of Financial Economics 73, 375-407.

Loughran, T., and J. Ritter, 2004, Why has IPO underpricing changed over time? Financial Management 33, 5-37.

Maksimovic, V., and P. Pichler, 2006, Structuring the initial offering: Who to sell to and how to do it, Review of Finance 10, 1-36.

McNichols, M., and P. O’Brien, 1997, Self-selection and analyst coverage, Journal of Accounting Research 35 , 167-99.

Megginson, W. L., and K. A. Weiss, 1991, Venture capitalist certification in initial public offerings, Journal of Finance 46, 879-903.

Mitchell, M., and E. Stafford, 2000, Managerial decisions and long-term stock price performance, Journal of Business 73, 287-329.

Rajan, R., and H. Servaes, 1997, Analyst following of initial public offerings, Journal of Finance 52, 507-29.

Ritter, J., 2009, Some factoids about the 2008 IPO market, Working paper.

Ritter, J., and I. Welch, 2002, A review of IPO activity, pricing and allocations, Journal of Finance 57, $1795-1828$.

Rock, K., 1986, Why new issuers are underpriced? Journal of Financial Economics 15, 187-212.

Safieddine, A., R. McLaughlin, and G. Vasudevan, 2000, Investment banks and their role in seasoned equity issues, Financial Management 29, 96-110.

Schenone, C., 2004, The effect of banking relations on the firms IPO underpricing, Journal of Finance 60, $2903-58$.

Shleifer, A., and R. Vishny, 1986, Large shareholders and corporate control, Journal of Political Economy 94, 461-88.

Sharpe, I., and L. Woo, 2005, Corporate control, expected underpricing, and the choice of issuance mechanism in unseasoned equity markets, Journal of Corporate Finance 11, 716-35.

Stein, J., 2002, Information production and capital allocation: Decentralized versus hierarchical firms, Journal of Finance 57, 1891-1921.

Wruck, H. K., 1989, Equity ownership concentration and firm value: Evidence from private equity financing, Journal of Financial Economics 23, 3-28.

Wruck, H. K., and Y. Wu, 2009, Relationships, corporate governance, and performance: Evidence from private placements of common stock, Journal of Corporate Finance 15, 30-47.

Wu, Y., 2004, The choice of equity-selling mechanisms, Journal of Financial Economics 74, 93-119. 